\title{
Rationalising a volcanic crisis through literature: Montserratian verse and the descriptive reconstruction of an island
}

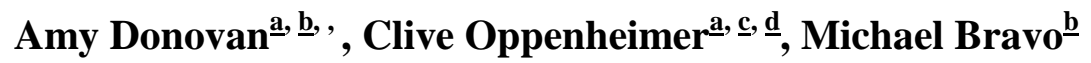 \\ a Department of Geography, University of Cambridge, Downing Place, Cambridge CB2 3EN, \\ UK \\ b Scott Polar Research Institute, University of Cambridge, Lensfield Road, Cambridge, CB2 \\ 1ER, UK \\ ${ }^{\mathrm{c}}$ Le Studium, Institute for Advanced Studies, Orléans and Tours, France \\ ${ }^{\mathrm{d}}$ Institut des Sciences de la Terre d'Orléans, University of Orléans, 1a rue de la Férollerie, \\ 45071 Orléans, Cedex 2, France
}

\begin{abstract}
This article discusses a selection of the literary output provoked and inspired by the eruption of Soufrière Hills Volcano on Montserrat - notably poetry and prose written by Montserratians affected by the disaster. It argues that literature can be a source of local knowledge, and a window into a culture that is seeking to deal with a tragedy. It can also be used to assess outreach efforts and to investigate the impact of volcanic events - and of volcanological information - on local populations. The texts describe the process by which Montserratians moved from bewilderment and denial to renewal and re-identification, and even pride in the volcanic activity and their own ability to live with it - and to help prepare other Caribbean islands for future volcanic events. Literature looks both backwards and forwards, communicating the acts of experiencing and changing. On Montserrat, that applies both to colonialism and the role of the UK in Montserrat's political, economic and social life, and also to the importance of learning volcanology, and welcoming volcanologists, as a means of survival.
\end{abstract}

Keywords: Montserrat; literature; poetry; risk communication; societal response; role of volcanologists

\section{Introduction and background}

\subsection{Montserrat}

The Soufrière Hills Volcano began to erupt on 18 July 1995, following three years of heightened seismic activity (Kokelaar, 2002). The eruption was initially phreatic, but juvenile magma was identified in the autumn of 1995, and volcanic activity has continued to the present, though with several extended periods of quiescence (Table 1; [Sparks and Young, 2002] and [Watts et al., 2002] ; Loughlin et al., 2010 and [Wadge et al., 2010] ). In 1996, the capital city of Plymouth was evacuated for the third and final time. It is now buried beneath 
pyroclastic current and lahar deposits. The population either emigrated or moved to the poorly developed north of the island. The eruption has provided a continual challenge to volcanologists, even as it has vastly increased understanding of the processes occurring (e.g. Druitt and Kokelaar, 2002 and articles therein). Even the nomenclature of volcanology has begun to unwind: is it a single eruption, or several? It would appear that for the population, at least, the eruption is regarded as continuous, since it has not been possible to reoccupy Plymouth: the terminology used has therefore been socially rather than scientifically defined.

The episodic nature of active dome growth (with pauses of up to two years' duration) has led to a 'creep-back' mentality, and on occasion a false sense of security. It has also resulted in a prolonged period of mourning for the old capital, Plymouth, and the villages in the south of the island that have been destroyed. The high level of scientific uncertainty concerning future activity has represented a major challenge for both personal and public planning and land management (Aspinall et al. 2002). At the same time, there has been ongoing dependence on the scientists, and occasional resentment towards them, particularly from some parts of the expatriate community. The relationship between science and Montserrat has worked both ways, with both sides learning from the other, as will be discussed below.

During the eruption, two thirds of the population left the island, and the same proportion of the island's territory has been rendered unsafe ( [Aspinall et al., 2002] and [Pattullo, 2000] ). The loss of many skilled workers depleted the Montserratian workforce, which in recent years has been partially replenished with immigrants, according to local officials. The diaspora has also become an important part of the community, however, as it continues to define itself ethnically rather than geographically, as described by one interviewee:

\section{Montserrat is not only the physical Montserrat, but all those thousands of Montserratians} who live abroad, and because of the use of the internet, you can sit at home in whatever part of the states you're from, and you can just log on to our live stream and you can get all the information you want about Montserrat. As they do, so we have a greater listenership in the diaspora than we have at home because we are only 5000 people. Broadcaster, May 2009

Prior to the eruption, Montserrat was an economically stable, flourishing British Overseas Territory in the Caribbean (Possekel, 1999). It had a lively artistic community, boasting Air Studios - owned by George Martin and the site of major music recordings. There was also an active literary community, notably around Sir Howard Fergus, but also in the works of journalists such as Cathy Buffonge - and the UK-based literature of the critically acclaimed E.A. Markham - and the island has a long history of literary activities (Fergus, 2004). In 1995, most of the population lived in the South, in and around Plymouth, and "the north" was disregarded by many: the land was less fertile, and very few people lived there. The destruction and ongoing hazard in Plymouth has shattered the island, and has forced the rebuilding not only of most of the basic facilities, but also of the identity and culture of the Montserratians. The regrouping of national identity using poetry and prose is the subject of this paper.

The management of the volcanic crisis on Montserrat has been very challenging, in spite of the relatively small population (Aspinall et al., 2002). It has also highlighted the importance of social scientific perspectives on volcanic risk management (e.g. [Haynes et al., 2007a] , [Haynes et al., 2007b] and [Haynes et al., 2008] ), along with similar studies elsewhere (e.g. 
Perry and Lindell, 2008; [Gregg et al., 2004] , [Cronin et al., 2004], [Bird et al., 2009], [Johnston et al., 2000] , [Johnston and Ronan, 2000] and [Barclay et al., 2008] ). These works demonstrate that the social context in which science is carried out is crucial in its successful communication. The argument presented below is that analysis of literary and indeed other forms of cultural expression can provide key insights into the response of particular cultures to volcanic activity (e.g. [Cashman and Cronin, 2008] , [Swanson, 2008] and [Chester et al., 2008] ). Recent work in social understandings of risk (e.g. [Kahan et al., 2009] and [Kahan, 2010] ) suggests that worldviews have a major impact on the ways in which populations respond to risks. This implies that cultural controls are extremely important and at the same time very complex - and this agrees with results in recent studies of volcanic risk perception (e.g. [Gaillard, 2008] and [Gaillard and Dibben, 2008] ). While direct studies of risk perception using quantitative assessments are helpful (e.g. [Aspinall, 2006], [Marzocchi et al., 2006] and [Marzocchi and Woo, 2009] ), these have to be supported by qualitative studies such as interviews, observation and documentary analysis (e.g. of newspapers, music and literature). This paper uses the example of Montserratian poetry and prose to draw conclusions about the role of literature on Montserrat and its potential usefulness for volcanologists seeking to work cross-culturally. The Methods section provides an introduction to the main methodologies used in this analysis. The following section deals with both disciplinary and local contexts. The disciplinary context refers to literary ideas that are relevant to the study of literature more broadly, and in the context of natural disasters more particularly. The paper then presents some examples from poetry and prose written on Montserrat and by Montserratians in the UK concerning their experiences during the eruption. These data are analysed using standard literary techniques, and in the context of social scientific research. Finally, the paper discusses the implications of the different themes that are traced in the literature. The specific aims of the paper are to (a) present and interpret examples from Montserratian poetry and prose concerning the volcanic eruption; (b) combine these observations with social scientific data collected on Montserrat; (c) discuss the implications of these results for understanding cultural responses to the eruption and its management; and (d) suggest that the integration of scientific and local cultures can be enhanced by consideration of local artistic expression, with considerable benefit to mutual understanding and therefore the communication of volcanic risk through outreach.

\section{Methods}

The analysis here is based on ethnographic research at the Montserrat Volcano Observatory, document and poetry analysis, and interviews with scientists, broadcasters, local officials and with Sir Howard Fergus. It is therefore heavily dependent on qualitative methods, which are not always readily accepted by scientists, but are extremely important in the social sciences. While these methods are very subjective, social science tends to have subjects rather than objects: subjectivity, analysed as objectively as possible, is a powerful part of social analysis. Some brief notes follow to aid readers less familiar with social science research methods.

\subsection{Ethnography}

Ethnographic research relies upon the researcher becoming a part of the community or culture that is the subject of the work. In this case, the researcher worked as a volunteer at the Montserrat Volcano Observatory, analysing geochemical data, for two field seasons of ten weeks each. This involved attending meetings and participating in fieldwork, as well as working in an office at the observatory. Ethnography allows the researcher to examine their own responses, frustrations, and impressions of an environment, and to describe it as an 
insider. It is regarded as an extremely robust method of cultural analysis by anthropologists (e.g. [Geertz, 1973] and [Latour, 1987] ).

\subsection{Interviews}

Interviews took place on Montserrat between April and June 2008 and March and May 2009. Further interviews were carried out in the UK in early 2009. Some of those interviewed had been involved in managing the eruption from the beginning, while others became involved more recently. The format of the interviews was semi-structured (e.g. Somekh and Lewin, 2005); this allowed the interviewer to provide a framework for the discussion around particular topics, but also gave opportunity for interviewees to focus on those areas that were of most interest to them. Interviews ranged in length from 30 min to two hours.

\subsection{Practical criticism}

Practical criticism is a method of literary analysis that looks at the structure and language of a text. Poetry in particular is an extremely dense form of expression, and each word is significant. The practice of criticism is highly subjective, and involves interpreting a text in terms of the words on the page - it can be done without any knowledge of the author, date or context of the writing. A strength of practical criticism is that it allows for subsequent contextualisation: initially taking a poem out of context and then rereading it in relation to particular historical or social conditions allows for analysis of the impact of these conditions on the writing. The development of skills in practical criticism involves what Richards (1929) referred to as "literary judgement", something that is obtained through practice and experience.

In the present context, the use of ambiguity in poetry is of particular interest (Empson, 1930). The poetic medium allows for multiple meanings within the same phrase, which may be drawn from the positioning of words, the words themselves, rhymes and rhythms and other literary devices, or noticeable absences, to give some examples. Literary scholars have long since abandoned the author (e.g. [Barthes, 1967] and [Foucault, 1969] ): they argue that it is the meanings of the text that are important rather than the meanings that the author intended to present. Both author and reader contribute to the interpretation of the poem.

\section{Literary and psychological contexts}

This section will look in more detail at the role of literature in describing highly emotive events. The first part will argue that Montserrat has a strong literary history that was documented before the eruption (Skinner, 2004), and has continued during it, aided by the increased availability of printing and publishing, but not controlled by it. Secondly, the broader literary context will be discussed, and it will be argued that literature is widely regarded both as a source of cultural expression of extreme events (such as tragedies), and as a means of exploring psychological issues linked to the experience of these events.

\subsection{Montserrat's literary culture}

Skinner (2004) argues that Fergus's poetry is a "barbarian" response to colonial overlords, and discusses his role in the identification of Montserrat just before the eruption. Despite some factual errors, Skinner's account provides a useful record of Fergus' activities and of his motivations and views as expressed before the eruption, and it demonstrates the importance of 
poetry and creative expression in Montserratian culture. Fergus is still an authority figure on Montserrat - he has served as deputy governor since 1974, placing him right on the threshold between the Montserratian community and its British authorities. In the early days of the crisis, his unique and potent position enabled him to explain the need to evacuate to those unwilling to do so.

As acting governor I had the, well, unthankful task, the challenging task of going and asking people to move, and in the days when we didn't know as much about the behaviour of the volcano as we do now, there were times when I had to go to a village - let's say Long Ground, the village nearest to the volcano - asking them to move that same night... Sir Howard Fergus in an interview in April 2009.

The decisions that Fergus had to take, particularly early in the eruption, about the timing of evacuations and the management of the exclusion zone - which sometimes went against what local elected politicians thought - have given him a unique insight into the social aspects of crisis management. He has remained in Montserrat as its historian, with a deep appreciation not only of what separates Montserrat and the UK, but also what separates Montserrat and its recent experiences from the rest of the Caribbean islands. In 1996, Fergus published a small volume called Montserrat versus Volcano. It was a sister volume to Hugo versus Montserrat (1989), which he edited with E.A. Markham, and which included poetry inspired by the devastation of Montserrat by Hurricane Hugo in 1989. Part of the Montserratian response to disaster, it would seem, is to poeticise it. The volcanic crisis, unlike Hugo, did not dissipate: the threat remains. One of Fergus' poems, "Class", has six stanzas, each dealing with a different natural hazard. It culminates in the sixth stanza:

But volcano is boss man, only one in its class, man

It spouts fire and water from the same fountain

to blister and cool us. Hot mud on a spree

embracing all in its orbit from mountain to sea

turned emerald brown closed the town down

and to be frank ${ }^{1}$ has locked up the key

from the Governor-in-Chief compelling

lesser powers that be to beg for relief

That is classic, that is class.

The lack of punctuation and the enjambement (run-on lines) quicken the pace from the third line onwards, mimicking the pyroclastic flow as it heads down the mountain. This verse also uses Afro-Caribbean metaphors to "own" the volcano, even as it comments on the colonial system - the phrase "boss man", for example, contrasts with "Governor-in-Chief".

Montserrat's management of the eruption will have to take place within its political and cultural context, but is also contrasted with all previous experiences here. The volcanic eruption, unlike the hurricane, has an indefinite potential duration. It became chronic, and the 
sense of loss associated with it also became chronic, significantly impacting the identity of the island - social, cultural, geographical and psychological. The literary medium allows for the expression of these several layers of experience.

\subsection{Literary contexts}

The Romantic Movement in the late eighteenth and early nineteenth centuries relished the aesthetic challenge of representing nature in verse - the "sublime and terrible" (Ashfield and de Bolla, 1996). Through the nineteenth century, as scientific knowledge and opportunities for travel increased, poetry and prose continued to reflect the changing relationship between man and his environment. In "The Song of the Earth", Jonathan Bate (Bate, 2000) notes that "culture" is etymologically tied to landscape - it derives from "cultivated land". He traces the changing relationship between culture and nature in literature:

The business of literature is to work upon consciousness. The practical consequences of that work - social, environmental, political in the broadest sense - cannot be controlled or predicted. They will be surprising, haphazard, indirect, long-term. (2001, p. 23)

Poetry is a very appropriate medium for discussion about nature. It sits on a threshold, condensing meaning to few words, and surrounding them with blank, uncertain spaces. It may be deliberately ambiguous or contradictory, and its brevity is controlled by the author, but left to the interpretation of the reader - and to their imagination: "the idea of poetry understood not only as a particular use of vocabulary and grammar but as the spontaneous movement of language shifting in the space of human imagination" (Foucault, 1968). Communication is also an act of community and commonality: it draws author and reader together.

The sublime and the tragic are closely linked in literary history (e.g. [Boitani, 1989], [Shapiro, 1985] , [Eagleton, 2003] and [Poole, 1987] ). Discourses of tragedy in literary studies are voluminous: many of the greatest works of literature are tragic works - Hamlet, Macbeth, Paradise Lost (a phrase recently used by Montserratians to describe their island, with religious connotations), and the Greek Tragedies, for example. Poole (2005) captures some of the reasons for this:

'Tragedy' may connote inevitability and 'accident' chance, yet somehow they are embroiled with each other... History simply tells us what actually happened, but poetry aims at a higher and broader kind of truth... Where philosophy abstracts, tragedy particularizes ... Tragedies show the way words fail at critical moments. This is not the only truth that tragedies express, for they also show how words go on, how we go on in the teeth of disaster.

Literature has a corporate nature that is lacking in histories: the reader "suffers" with the author and characters, and this act in itself is cathartic: tragedy is "through the arousal of pity and fear effecting the katharsis of such emotions" (Aristotle, 1996). This relates to the idea of the sublime, mentioned above, and defined thus by Burke, 1757:

Whatever is fitted in any sort to excite the ideas of pain and danger, that is to say, whatever is in any sort terrible, or is conversant about terrible objects, or operates in a manner analogous to terror, is a source of the sublime; that is, it is productive of the strongest emotion which the mind is capable of feeling. 
Volcanic eruptions may be regarded as sources of the sublime; that is part of their appeal to volcanologists and poets alike, in the act of imagining "boundlessness" (Kant, 2005). Poetry humanises the experience of the sublime in nature:

In reality, poetry and rhetoric do not succeed in exact description so well as painting does; their business is to affect rather by sympathy than imitation; to display rather the effect of things on the mind of the speaker, or of others, than to present a clear idea of the things themselves. (Burke, 1757)

In a volcanic eruption in a populated area, the sublime and the tragic are interwoven:

Tragedy is only a way of assembling human misfortune, of subsuming it, and thus of justifying it by putting it into the form of a necessity, of a kind of wisdom, or of a purification. (Roland Barthes, quoted in Poole (2005, p. 62))

Tragic literature is an expression of a cultural, corporate suffering, inviting identification and purgation - and indeed the formation of new identities. Like the sublime, tragedy depends upon a human mind for its definition and experience.

Montserratian literature, like that of other islands in the Caribbean, is poised on the threshold between local and colonial - unable, quite, to escape the past (Markham, 1989; see also Wilson Harris' Palace of the Peacock) - and this is expressed through religious, social and political imagery. This is demonstrated in Montserrat's history in the increasing identification with the Irish (appropriately for the Anglo-Irish Edmund Burke, above), with St Patrick's Day celebrations being nationalised in 1985 (Fergus, 2004). Thus there is a simultaneous motion towards and against the colonial powers, which is reflected also in the tragedy of the eruption: had Montserrat not been a UK territory, it would have avoided UK mismanagement ( [Clay et al., 1999] and [Pattullo, 2000] ), but also not received the financial support on which it now depends. This contradiction is keenly felt in the political history of the last fifteen years and in the poetry as it chronicles struggles with science, scientists, and colonial powers, and helplessness in the face of natural majesty. The tension between the beauty of the "Emerald Isle" and the destruction of the volcanic activity - whose past eruptions had produced much of the pre-1995 verdant landscape for which Montserrat was so famous - is clear throughout the poems, and resonates with the conflicting emotions of the sublime and tragic.

The political dimension of the sublime, expressed in Burke (1790) later works, and in Kant (2005), is also worth mentioning in this context — not least because of Burke's Irish origins. Burke compares the sublime British establishment with the failing French aristocracy, in his famous Reflections on the Revolution in France, invoking its masculine austerity, respect for authority and reverence. Kant, meanwhile, regards the Revolution as sublime itself, in bringing progress and freedom - ideas closely associated with sublimity in his Analytic. In a sense, then, the Burkean sublime can be associated with the old colonial British empire, Montserrat's historical security - but also a potential source of revolution and discord - the Kantian sublime. This aesthetic context is relevant because it describes the tension inherent in the colonial situation on Montserrat, between the rich grandeur of the colonial past, and the less ordered, vibrant Caribbean influences. It also provides an important backdrop to the volcanic crisis, in which the different levels of resources available to local and British scientists were apparent, as were cultural differences, and the cause of considerable tensions within the scientific community, while political manifestations of the threat to Montserratian 
independence brought down several governments in the early years of the eruption ( [Fergus, 2004] and [Pattullo, 2000] ) (Fig. 1).

Behind the individual Montserratian narratives, and the historical progression of the eruption, are metanarratives of a small island community trying to survive whilst at the mercy of a volcano that may continue to erupt with varying degrees of ferocity for the foreseeable future. It seems that there are a number of stages in the social adjustment process, and they reflect some of the stages of grief as identified in the psychological literature (italics: grief stages according to Kubler-Ross, 1969).

\section{Uncertain, fear-driven protest, anger and denial \\ 2. Realisation and time-critical adaptation (evacuations etc.) \\ 3. Mental adjustment, decision-making - stay on Montserrat or leave - bargaining and depression}

4. Guarded, hopeful progress and continuing reassessment - acceptance

Each of these stages is fluid; there may be fluctuations between them: their temporal succession is not straightforward. However, they may be used as a skeletal guide for assessing the narratives within the social structures on Montserrat, particularly in relation to the growing semi-scientific knowledge and awareness in the community. 'Studies of Expertise and Experience' ( [Collins and Evans, 2002] , [Wynne, 2003] , [Jasanoff, 2003] and [Fischer, $2004]$ ) may inform this narratology in a number of ways: many citizens have developed rudimentary volcanological expertise, based both on reading and on experience. They notice trends in the activity, and draw conclusions on the basis of their observations. This itself is scientific, in the broadest sense, and often not without merit, as several interviewees noted.

Literature is a targeted and precise means of cultural communication. It enforces shared experiences, and provides an emotional outlet for them. The verse and prose considered here is a form of local knowledge: Montserratians are experts in coping with volcanic crises, because there have been many in the last fifteen years. This extends beyond the practical and into the emotional: how do volcanoes affect people? What do local people notice the most? How can they be better prepared in the future? What kinds of help, understanding and practical assistance make the most difference? These questions are crucial in managing volcanic crises and in the communication of relevant information to communities that are at risk. The writings of the Montserratian community - diverse as it is - then, are worthy of consideration by volcanologists seeking to prepare other communities for potential disaster and diaspora (Cashman and Cronin, 2008).

\section{Results and analysis}

The next few sections of the paper describe some of the themes and messages running through the poems. Initially, the focus will be on examination of the very early poems, in Montserrat versus Volcano. This little book demonstrates the importance of the poetic medium and directly relates it to the volcanic crisis: the book contains scientific information, excerpts from Wadge and Isaacs (1988) and photographs, as well as poems and prose. It is therefore a unique record of a culture responding to a crisis. This focus on the early part of the eruption will also include some analysis of later writings by Yvonne Weekes and Dorine O'Garro. 
Both of these writers left Montserrat because of the eruption. Their memories of the early years are useful records of the experience of losing their home.

Following on from this, several key themes will be expanded in detail. This part of the discussion deals with poems written throughout the eruption, and discusses their value in understanding some of the social impacts that it had. These themes are ultimately linked by the idea of national identity: Montserrat's small-island culture was hit on several sides by the volcanic event. First, the influx of foreign scientists from multiple disciplines was a significant event for a population that generally know one another. Second, a major challenge in crisis management was posed by the colonial status of the island - this was compounded by the fact that the UK government was faced with antagonistic responsibilities and motives in handling the crisis ( [Aspinall et al., 2002] and Aspinall and Sparks., 2004). For example, while the Governor is personally responsible for the safety of the people, disaster management was the responsibility of the locally elected government. In addition, there were colonial tensions that are clearly reflected in the verse. Finally, the process of mourning is described: Montserrat was proud of its island, its people and the natural beauty of the South. In addition to losing 19 citizens as a result of pyroclastic currents emplaced on 25 June 1997 (Loughlin et al., 2002), they lost their capital city, and highly symbolic aspects of their identity - not least a substantial part of the "emerald" hills that give the island its popular name.

\section{Culture adjusting its relationship with nature: Montserrat versus Volcano}

Montserrat versus Volcano (Fergus, 1996) contains extensive information regarding public perception and interpretation of the eruption, and understanding of scientific facts and capacities in the very early days. It includes some children's poems: the schools in Montserrat encouraged children to write poetry as a means of expressing their emotions during the crisis (Cashman and Cronin, 2008). It also includes poetry by a number of adult authors. The poems combine binary oppositions in an attempt to rationalise the short-term experience and the huge re-education they have undergone: there is a form of extreme nostalgia - the realisation that the past has gone and can never be reclaimed. Some years later, Yvonne Weekes, who had left Montserrat during the eruption, wrote:

In all the years growing up and living on the island of Montserrat, I never once remember thinking about her. I don't remember what she looked like. I don't remember even noticing her. She was simply there. I only know that she came into by consciousness when she first blew that hot July in 1995. Before that day, she was never there for me.

This then is the beginning of time. (Weekes, 2006, p. 15)

Montserrat has come to define its recent history as before volcano and after volcano. In 1996, however, even the need for cultural redefinition was uncertain: the scientists were unable to say how long or how big the eruption would be, and communication had been fraught with cultural and financial difficulties between different scientists ( [Pattullo, 2000] and Haynes, 2005). Education programmes were disorganised at first (in 1995), and involved scientific information being relayed to the public by the media or local officials, rather than directly from the scientists - a problem that was identified relatively quickly, and rectified, as the local radio began to interview scientists directly. Educational materials were produced, and the language of volcanology rapidly permeated the Montserratian consciousness: poems in the 1996 book have titles such as "E.D.M." (for electronic distance metre), "Volcanotectonically 
inclined", and "Broadband Tremors", as the writers read the terms back into their experiences. One of the most notable aspects of the poems is that many anthropomorphise the volcano as they seek to relate to and about it, and to adjust their identity in accordance with its thrall. Thus the volcano is described as an adolescent, or as one undergoing a mid-life crisis. In other works, it is an angry husband, one who cannot be divorced "because you have got/children and property!" One piece summarises the old and new implications of the "smell of sulphur". The old, familiar meanings are described in prose, with a nostalgic, forlorn tone — hiking up to Galway's Soufrière, or chemistry class at school. Then the poetic voice echoes the urgency of the present:

Now the smell of sulphur means:

Get tense

Get on the alert

Locate your dust mask

Look for shelter

Mentally review your contingency plan...

(Magrit Wess, “The smell of Sulphur”, in Montserrat Versus Volcano)

In an interview in April, 2009, Sir Howard described Montserrat versus Volcano as a "crude little book", and has published more refined and mainstream collections of verse. However, it is nevertheless a unique cultural expression at a time of acute distress and uncertainty, including information about the eruption written by both scientists and local journalists, alongside impressions and testimonies, and poetry by both adults and children. It brings out several important points about Montserratian culture, which give scientists some insight into the local population.

The poems are permeated by the deep Christian roots of Montserratians. The working out of God's will in the eruption is a key concern and remains so. Fergus is a man of faith and a church elder, and although he thinks that the workings of God are not so simple that the eruption is in some way a direct punishment on Montserrat - he does not think Montserratians are "any worse" than other peoples - he acknowledged in a recent interview that this is something that many Montserratians still struggle with. There remains in Montserrat a Christian hope that the eruption will end, and a trust in God because of the way they have seen provision in the crisis (e.g. Weekes, 2006; see also Chester, 2005). This demonstrates a deep appreciation of the island's natural beauty, and even to the majestic aspect of the volcano's power as it takes away the verdant and much-loved slopes of the Soufrière Hills, here compared to the hills of Psalm 121:

She was my pride and joy

"I will lift mine eyes unto the hills"

Emerald Isle, green hills, green fields... 
...The sun shines again and again

No trees, no grass

my love is naked and bare.

Now I see her as she really is; strong, proud, defying

All giving me strength to fight, to survive.

Now she is beautiful.

There is beauty too in nakedness.

\section{(E. Karney Osborne, "Volcano's gift”, in Montserrat Versus Volcano)}

This illustrates the ambivalence of the Montserratian poet: there is something deeply attractive even in the devastation. Firstly, it is their devastated island: there is an ownership, an identification with the mountain. Anthropomorphism, similarly, is a form of identification, evoking a humanity that is projected onto the volcano and then related to by the writers. It is a device for familiarity, and therefore encourages learning and dialogue. The "natural world" is as slippery a concept as is culture in the twenty-first century: people are encouraged to get back to it, to care for it, and to flee from it. Montserrat's experience is fully representative of those conflicting impulses (Fig. 2).

Montserrat versus Volcano is also a statement. It represents the Montserratian claim on the crisis. In the preface, the Governor, Frank Savage, compares the Montserratians at Christmas, 1995 to the Holy Family, unable to find proper shelter, but looking out for one another. In his historical overview of the volcano itself, Sir Howard makes an important point:

In the heat of the present seismic activities, the Government of Montserrat relies on the readings and analyses of the scientists on a daily basis. The danger is, if and when this seismic crisis subsides and the volcanoes assume a so-called dormant posture. It is very likely that seismic-volcanologists will continue to research, write and publish in journals and organize conferences. Some mechanism must be found for keeping Government abreast of the findings of the specialists. The public is sometimes cynical about academic research seeing much of it as esoteric, ivory-tower and confined to a small universe of scholars. Studies in volcanoes bear directly on life and development. This is one area in which it can be catastrophic to divorce academia from practical planning.

The dangers of divorcing academia from planning have been witnessed on many occasions, not least the Asian tsunami in 2004 - research requires translation into practice. There was an urgency in the early months of the eruption to ensure that people accepted the warnings they received as valid and not politically motivated (Pattullo, 2000). Science could act as a mediator between politicians and public: he goes on to stress the need for "knowledge from the scientists in digestible form to help them cope with these fears; they must know that Government plans are underpinned by authentic knowledge", but concludes that "I think they are". This in some respects sums up Fergus' approach: he draws attention to questions, to gaps and to problems, but ultimately seeks to reassure people. This is the case too in his later work. The plea of this little book, then, is for a sympathetic and sensitive approach to public 
education that takes into account the social upheaval that is being experienced. Interviewees suggested that while education about the science was extremely important in helping them to understand why they had to move, it was significantly more successful where they felt that those explaining it were sympathetic to their situation.

\section{Narratives of change: "My poor little Montserrat"}

Montserrat has had to accept that in the medium term, at least, Plymouth is irrecoverable. Fergus believes that they have accepted that and have learned to live with the volcano. His later poetry, based on longer-term reflections, reveals his impressions of the crisis, of Montserrat, and of the scientists. Contextually, it spans the first pause in volcanic activity, which lasted eighteen months, and during which many islanders celebrated the end of the eruption. The renewed activity of November 1999 was a catastrophic blow, and resulted in considerable emigration. Montserratians who have remained on the island to date are desperate for the return of those who left: the population is currently not sustainable, and the despair is occasionally expressed in the verse. The act of coming to terms with the eruption took many years, and was a very personal, corporate experience of grief, from denial to acceptance - "they were surprised that things could change so fast" (Dorine S. O'Garro, "The road", p. 99). Arguably, the acceptance is very recent.

Dorine S. O'Garro, and Yvonne Weekes, both of whom left Montserrat during the eruption, have written prose and verse accounts of their reaction and feelings both towards the volcano, and towards their Montserrat. O'Garro (2004), describes the process by which Montserratians progressively learned of the potential dangers:

At first, everyone treated the volcano as a nuisance. They hated the ashes that covered everything. Soon the ash flow was not their greatest concern. Magma began to flow, and sulphuric and other gases filled the air. The first victim of the volcano was the vegetation. The hot ashes scorched it, and the once green mountains were covered with gray, ghost-like trees and shrubs. (Dorine S. O'Garro, "The Calabash Man", p. 82)

Narratives from the early days of the eruption concern the green-to-grey transition, a particularly poignant one for the "Emerald Isle". The repeated evacuations, and the darkness from the ash clouds constructed the idea that properties and villages would be lost, wrenching people from the land they were so grounded in - many Montserratians had had their land in their family for generations.

The first eruptions claimed my family's property, burying it deeply in tons of pyroclastic flow. It was sad enough to lose the old house and the two acres of land, but I cried for the old coconut palm, for like all of my ancestors, it too was lost forever. (Dorine S. O'Garro, "A very special tree", p. 2)

As the activity intensified, the impact spread across the south of the island.

Originally, there were five dormant volcanoes on the Island of Montserrat, but soon they began to pop up all over like wild mushrooms.

Day after day the news got worst. Farmers could not find feed for their animals. The animals were dying. People began to worry, as scientists from all over the world visited the Island. The once forgotten Island was finally on the map. They spoke of it as "Paradise lost". When 
Aaron saw the program on CNN, he remarked, "Too bad they didn't know it when it was Paradise found." (Dorine S. O'Garro, “The road”, p. 96)

The reference to "five dormant volcanoes" relates to the lava domes from previous eruptions at the SHV. Each is associated in O'Garro's work with a direction of activity - thus, she talks about "the Gages volcano" as separate from Galways and Chances Peak, for example. The volcano is defined not by its magmatic source but by the local names for the domes. Again, there is social rather than scientific definition of the volcanic activity. There is also in this passage a hint of resentment that the volcano has somehow imparted an interest in the island that was not there before - that it has been noticed by the world, as it deserves, but for all the wrong reasons.

Descriptions of the volcano tend to personify it, in a variety of different ways - sometimes it is angry, others it is gassy:

"You belch now and then. I belch more often. The volcano is belching. She has gas in her stomach, lots of gas according to the men of science. When she's tired belching, she'll stop.”(Dorine S. O'Garro, “The road”, p. 97)

The identification of human living and the processes involved, and the volcanic processes, is a potent metaphorical teaching tool. There is a modicum of comfort in anthropomorphising, and also a sense of ownership. On the other hand, it can also limit the imagination and refuse to consider the possibilities. The power of experience has been demonstrated on Montserrat, most notably in the aftermath of the deaths on 25th June, 1997.

Corporate mourning, a repeated theme in the literature, has been a process by which Montserratians have rebuilt themselves:

It's a type of therapy too. And for us, in Montserrat in particular, because we have had this traumatic experience for so long it's important that we provide this kind of an opening for people to talk, get things off their minds... Broadcaster (2008)

This comment refers to the role of $\mathrm{ZJB}$ radio Montserrat, which has had a key role not only in informing people about the volcanic activity via live broadcasts from MVO, but also in allowing people to express themselves. Montserratians overseas can listen to the radio over the Internet, and make telephone contributions: this maintains a sense of community through communication. ZJB has a very clear mentality - almost ideology - of Montserrat as a global diaspora with a single root.

\section{Scientists}

The scientific community that descended on Montserrat in 1995 was somewhat baffling to the citizens at the time - their learning curve was almost vertical and the key feature of that learning was that volcanologists don't know very much about volcanoes:

The scientists, with all their claim

to inside intelligence, cannot truly tell

when a dome collapse will come to pass. 
The volcano dances to its own music;...

I wonder will it crack in the new year

spilling its insides

in a dramatic show of openness.

No need then for scientific hieroglyphics

for a season. In plain language

All of us will know.

(Fergus, “Openness: 2.1.2001”, in Volcano Verses; Fergus, 2003)

This poem is not critical of the scientists; rather it expresses different kinds of knowing. Its title, "Openness", is an ironic expression of the fact that "man has heights to go to fully fathom nature": scientific knowledge is of a different kind to the overwhelming force of experience. Scientific "hieroglyphics" are dwarfed for the wider public by the force of the events they refer to, events which are "plain" and inescapable. This poem also echoes a much earlier poem, "Scientists know", which asks, "Will the scientists ever know?" And then answers "I trust that the scientists know". This poem dates from October 1995; the later one from 2001. The ambivalence in both is emphasised by the end of the lines: the uncertain space where the poem transfers to the reader.

Fergus' portrayal of the scientists also comments on the multidisciplinary nature of volcanology:

Custom-made 'ologists' up-market doctors

with long-distance thermometers

monitor the health of soufrière...

(Fergus, “Update: No significant change", in Volcano Verses)

The first line echoes another, much earlier poem, "Volcano watch", which is written, like several others, in the style of a eulogy. It refers to the "multiple observatory posts/and the feverish multi-ologist scene". The variety and number of scientists who worked on Montserrat in the first five years of the eruption was commented upon by many Montserratians, who confess themselves unable to remember names and faces. Several interviewees mentioned the challenge of distinguishing between seismologists, geologists, petrologists, geochemists, medical practitioners and geophysicists: understanding the roles of different kinds of information in the "jigsaw" took time. This sudden influx of people on whom they had to depend so deeply was baffling to a culture that was strongly arts-dominated. The media thus played a very important role in the translation of science to Montserratians.

...A corps of scientists knock 
heads, peep through instruments, plot graphs

to bring us comfort and despair in unknown tongues

with local echoes. Montserrat media

learn the lingo fast...

(Fergus, "Volcano Watch, August 1995" in Montserrat Versus Volcano)

The confusion of the Montserratians as the scientists invaded their culture at the highest level of governance, and the suspicions about different groups of scientists, and their apparent proximity to the UK government are clear too from Yvonne Weekes' account of her experiences: the question of who could be trusted in the midst of life-shattering news added to the uncertainties. Again, the overwhelming impact of the eruption is described:

They continue to talk in some high-flown language about silicosis, and acid rain, and respiratory problems, and masks, and electronic distance meters, and seismographs and shortening of lines, and all kinds of language which I feel sure is designed to confuse the people and keep them in ignorance.... but we leave the meeting having swallowed..every word those politicians and scientists say, even though we've been looking at the mountain for days and full well know that she looks deadly.

There were conflicting messages, rumours and orders, as scientists, politicians and the public tried to find their feet amidst the ash fall. This has been described at length elsewhere (e.g. Pattullo, 2000), but the poetry and prose accounts add the personal dimension, juxtaposing impressions, experiences and thought processes. A recurrence in both art and interviews is the idea that "volcanology is not an exact science...the scientists don't know one cricket thing": scientific uncertainty rapidly penetrated Montserratian consciousness, where it interacted with mythology (Vulcan's wrath after the destruction of an Amerindian burial site, for example), theology and culturally specific thought patterns. Thus, Weekes writes about the reassurance of a science meeting held in a church, but also questions the need to calm the Caribbean spirits by a "jumbie dance": "I am willing to call upon these Caribbean spirits, or any spirits, if they will help".

One aspect of the initial management of the eruption has been the role of local scientists, and the need to import resources from the UK and USA to supplement the efforts on Montserrat, once the scale of the eruption became clear. Yvonne Weekes writes:

I notice that all kinds of officials of various shades arrive and there are secret and seemingly high-level discussions about which people are very suspicious... I notice that the Governor and a set of White scientists are sitting huddled together. Even though the volcano is monitored by the Seismic Research Centre, which is based in Trinidad, no scientist with my complexion is ever there. I am not the only one who notices these discussions.

She also expresses frustration at the British media for exaggerating the scale of the activity, "systematically putting out information which is misleading and false". She admits that at this state - early on - most Montserratians could not believe that the mountain was dangerous "the catch phrase is, Scientists are still viewing the mountain with concern". Ups and downs in the eruptive activity simply exacerbated coping with it - people did not know the 
timescale or the full spatial extent of the activity. At the same time, cramped living conditions in shelters, the lack of infrastructure and the absence of the familiar - "the first time in Montserrat that I get lost" - breed uncertainty and frustration. They also breed stories, however - "some are sad and others are very funny", the desire to "tek bad tings mek laugh", as in Weekes' theatre production "God will find a way", and the volcano "cannot take away those stories". Weekes' presentation of scientists is not flattering, almost resentful that they could not do more: "with all their fancy, sophisticated machines, the scientists have once again been caught off guard", in response to the 17 September 1996 explosion. The lack of predictability of the eruption, coupled with the fact that the scientists were not experiencing the loss that Montserratians were experiencing, and were, in many cases, not of Caribbean descent, caused problems for Weekes and was also mentioned by interviewees (including some scientists). While the importance for scientists of having local knowledge is clear, there is also a need to be seen to have it - to use local names and references, for example. Weekes' overriding concern is that Montserrat is being taken over by the British, and her view of the scientists is tainted by it. The impact of the initial phases of grief - especially anger - on those closest to the sufferer can be painful, and sometimes scientists experienced this, exacerbated by the perception that they were outsiders.

\section{The colonial tensions: "a tropic paradise under a British sky"}

One of the key problems in managing the volcanic eruption on Montserrat was that of its complex political structure: the Governor was appointed by the Foreign and Commonwealth Office (FCO), but much of the emergency funding came from the Department for International Development. Prior to the eruption and the hurricane in 1989, Montserrat had been approaching financial independence. It is now completely dependent on aid from the UK ( [Pattullo, 2000] and Donovan, 2010). This has complicated relations with the UK further, and it is evident in local writings: Fergus writes "We lean on England's cold/shoulder", the line break highlighting the most obvious difference between Montserrat and the UK - their climates. He goes on to say "...to weather the rocks; / we slip and we slide sometimes fall/through the cracks": this is a recurring theme in Montserratian writing, and in reports written by outsiders such as Polly Pattullo - Montserrat was not given the support it needed when the eruption began, and was criticised by the Minister for International Development, Clare Short, for wanting "golden elephants". This has not been forgotten: "We wait upon the mercies of Jehovah and Clare Short", mocks the last line of one poem.

Montserrat's position as an Overseas Territory has been underscored repeatedly by the crisis, which has humbled the population and brought the island nation to a renewed dependence on the UK. At the same time the local population felt that the UK was holding back. One of Fergus' poems from December 2000 describes the imbalances: "we were tall on checks and check points, but short/on balances and false scales shared our cotton". The position of "short" on the end of the line is once again a reference to the Minister. The UK and the volcano are paired in this poem:

....They took away Bramble

that flew in up to forty in a dash

and gave us rude seas, toys and novelties:

a chopper and a heliport for the middle 
passage to Antigua at a high price -

the mortgage of a flying future.

(Fergus, "Volcano audit", 27.12.2000" in Volcano Verses)

The loss of Bramble airport in June 1997 was a major blow to the island, and the DfID was slow in responding to the rebuilding needs, with endless consultations and a solution that remains unsatisfactory for many Montserratians. Not least the problem arises from the death blow to tourism: "...only diehard tourists fixed with wings/and stoned on natural exotica will be passing/there for years." The major setbacks to the tourist trade continue to be felt on Montserrat. Interviewees from the Tourist Board expressed frustration that it is still not safe to run tours to Plymouth, for example.

Montserrat's dependence on the UK, coupled with the conditions in the shelters and the complete lack of privacy and resources was heavily criticised by the UK government's review (Clay et al., 1999). The offer of relocation in the UK was too little, too late.

In a rare fit of generosity they took

away our fertile south and signed us up on welfare

but we did not fare well. It was goodbye

to comfortable beds. Like Soufrière, we suffered

a change of colour - our culture is in the red.

(Fergus, "Volcano audit", 27.12.2000" in Volcano Verses)

This poem is entitled, "Volcano audit", and expresses some of the frustrations felt by Montserratians concerning the response of the UK government. It also refers to living conditions - many Montserratians lived in schools or churches for several years after Plymouth was evacuated. There is a very strong sense of powerlessness at the hands of God, nature, and the UK.

The mountains have come down and spoken

with granite authority: let Plymouth close

and what we shut no Brand ${ }^{2}$ can open.

No abbot or Clare Short is equal

to Soufrière's awesome power to convert;

the Belham river rose into a valley of Ezekiel. ${ }^{\underline{3}}$

(Fergus, "Beloved island - Those whom the gods love die young: 17.12.2000", in Volcano Verses) 
The poem is framed with theological images and language, expressing confusion at Montserrat's suffering, along with a reflection on the power and will of God - "the loving wrath", whose flood is "drowning Noah's/with fiery avalanches, rocks and coffee mud." There is a stark reality in these words: there is no room for comfort, but an acceptance of hardship ("a bitter pill...I take the pill"). The repeated image of transformation, and of taking away, converting Montserrat as it lies powerless to an "unarctic winter", "the Soufrière creep/that steals and corrupts properties", is overlaid with references to the financial and social problems with political roots.

The volcano is no estate slave; it gets red hot

with rage at pressure from inferior management.

Living in a crown land sanctuary

it knows its rights and threatens to erupt

unless the order comes from higher up,

direct from England. No prince consort, worse still

Clare Short, for since this Sabbath isle is colony

it bows to nothing short of summit majesty.

(Fergus, “Truce: 23.12.2000” in Volcano Verses)

This is an angry stanza, combining contradictory arguments to express frustration with the colonial status and dependence of Montserrat, the mismanagement of the crisis by the UK and the powerlessness that many Montserratians felt in the face of both the volcano on one hand, and the UK on the other. Montserrat's dependence on the UK for its recovery and rebuilding continues to be a major concern to those interviewed, particularly in a time of financial crisis (Fig. 3).

\section{Eulogies, but "still paradise"?}

Fergus describes Plymouth in May 1999, when the eruption was in a "pause" and many believed that it was over:

I tried, head bowed, a minute's mark

of silence - just a minute of respect

for a lost loved one,

but the sea and deafening silence

of the scenery stranded my efforts

at just a minute of respect. 
(Fergus, “A minute silence: 24.5.1999”, in Volcano Verse)

The impact of this verse is perhaps best understood in Plymouth itself (Fig. 5). The loss of Plymouth to a volcanic desert, burying many of the buildings and rendering the whole area treacherous, has had a huge impact on Montserrat's identity. Poems from Fergus and other writers describe that loss, the body politic and the natural body of the island being closely linked and feeling the pain of the other.

The period of April 1996 to August 1996 is the most difficult and trying period of my entire life. It is also the most creatively challenging and exciting... I never knew before how fulfilling it is to truly give. (Yvonne Weekes, Volcano: A Memoir, p. 50.)

This tragic duality is not unique to Weekes: broadcaster Rose Willock, among others, has expressed the positives of the eruption, not least in bringing people together in the shared experiences of evacuation, relocation and loss. The power of the volcano is a hugely intense experience, affecting everything, changing everything and yet bringing something too: the creative performance described by Weekes, contextualised though it is in the overcrowded shelters, is an example of the power of humanity in tragedy. Tragic writing defamiliarises the familiar and re-presents it to the reader, devastatingly changed in form and meaning. On Montserrat, this is what has happened to the landscape itself.

My deepest memories are being burnt away

One by one;

My childhood gossip buried in an avalanche

of billowing ash.

You cannot understand that at night a tiny grain

Of dust in my bed can awaken me,

Though it is merely innocent fluff that has settled.

I should feel safe, but I don't. I am in a foreign land

And homeless.

They've told me that I am welcome here,

But your prayers are rarely for me.

I'm too close

Bosnia is much safer.

(Yvonne Weekes, Volcano: A Memoir, p. 95) 
This poem, also by Weekes, tells the tragedy of the colonial tensions: it alleges that people would pray for the war in the former Yugoslavia, but not for Montserrat, because it was "too close", an implicit colonial criticism, better not acknowledged. At the same time,

Montserratians in the UK, like Weekes in Barbados, felt alienated and isolated:

When you speak of your recent marital tiff -

A mundane expression of everyday living....

I understand as part of all human experience,

But the flagellation of my country, where nothing

Will grow, you cannot understand...

The fear that everyone I know has vanished and

No graves are marked...

I am afraid to think of all that emerald turned

To deathly white.

(Yvonne Weekes, Volcano: A Memoir, p. 96)

There is a fierce declaration of uniqueness here: the distinctiveness of Montserratians, being swallowed up by the highly populated, general, disinterested UK. The transition from a small island community, with tropical weather, where people knew each other, to the faceless and cold UK was forgotten by those who thought that the Montserratians were being looked after by the offer of free passage and benefits.

Weekes' account also contains some striking descriptions of the not-knowing, the helplessness mingled with fear for both life and country

Suddenly there is darkness like the end of the earth. Darkness while the world is crashing. Even though there are eight of us in this room together, I feel a total solitude. This is all... The world wails a loud lament. It crashes into my senses. The electricity goes off. More darkness. Radio Montserrat goes dead. The phone is dead... I cannot risk moving for fear that the mountain will get even angrier. As the black clouds carry the sun away, I cannot tell if the light that peeps its way into the darkness, into the stillness, into the mud, is the light which will return my muddy island to its old time, or whether this is the beginning of a new time. In this world of darkness time is endless...Everyone is terrified and shaken. There are no words from any of us, no words at least for an eternity.

This reads like the rebirthing of an island and its people. The depth of thinking that is imposed by the brush with death has been described by many Montserratians, and in spite of the ongoing eruption, there is hope mingled with their frustration. Dorine O'Garro describes a brief visit "home":

There are no boundaries, just a twisted mess, 
I may be standing on my old home. It's only a guess

But out of the silence of the mangled plain,

Someone whispers softly, "Montserrat will rise again."

During the first pause, when many people thought that the eruption was over, Fergus wrote of "grins of glory dawning/on my people's faces now", with the feeling that they were "glad to be alive on the other side/of trial". This phoenix-feeling, described elsewhere in the poetry and narratives from Montserrat, is an example of the power of imagination and creativity in a crisis. When Dorine O'Garro describes a dream in which she imagined that she could turn off the volcano using a valve, not understanding why no one found it before, she is expressing uncertainty in a creative way.

This idea of the non-knowing is expressed in a number of ways in Fergus' poetry:

This once loquacious little town

is now forever silent

or on a long fast for speech;

no more hallucinatory snores

no love's loud ecstasy

no pulse. Plymouth is comatose

Or dead.

(Fergus, “A minute silence: 24.5.2000” in Volcano Verses)

The key here is that the poet does not know whether or not Plymouth is dead. The lingering "comatose" at the end of the line emphasises the uncertainty. It is closely associated with silence:

Where taxi tempers flared

And drivers cursed each other's

Mothers's red light road,

A long Sabbath of silence reigns.

(Fergus, “A minute silence: 24.5.2000” in Volcano Verses)

The rapid pace of the penultimate line contrasts emphatically with the long last line, with the reference to "Sabbath" highlighting that the poet cannot do anything to change the situation other than wait. Frequent themes in these poems are patience, alongside perseverance and faith: Montserratian "god-fearing" coping strategies. In this respect, perhaps, the cultural 
experience of uncertainty was tempered by religion, if occasionally confused by it. This does however represent a potential culture clash between many of the scientists and the local people, and demonstrates the importance of local knowledge in finding appropriate media for communication. One local official commented:

Full of respect for the role of the churches - one, they gave up their churches to be used as shelters, number two, we worked with the clergy of the day fourteen years ago for them to help put the message out through the pulpit, which they did very effectively, so I think they responded very well, and I don't think there could be any shortcomings... Very Christian community, so the clergy had a big role to play. They basically told the people listen and make sure that you understand.

The image of refinement by fire is one that recurs in the poetry, alongside the phoenix images, and is a clear reference to the biblical portrayal of suffering as a means of purification paralleling the expression of the tragic in literature. It does not, however, imply causality that suffering was caused by the evil of the people (Chester, 2005): the focus is rather on improvement through adversity.

Objects of mourning in Montserrat were not limited to the visible destruction and the emigration of two thirds of the population. The loss of dignity - individual and corporate - as development started to regress and people had to live in the shelters for prolonged periods, and "trecked from south to north" - backwards - was total and deeply felt. The DfID was vilified the most, perhaps, since they had control of the budget, and were widely regarded as stingy in the extreme (by scientists as well as locals - Donovan, 2010).

Dfid is not difficult as imperial bureaux go

Just mercilessly accurate and generously slow.

(Fergus, "DfID”, in Volcano Verses)

The transition from near-independence to total dependence was costly to national identity, yet there developed in parallel a volcano identity. Thus, Montserratian officials have helped other Caribbean islands devise volcanic risk management programmes, for example. In the aftermath of Hurricane Ivan, which decimated Grenada in 2004, Montserrat sent disaster assistance through the Caribbean Disaster Emergency Response Agency (CDERA). Their regional identity has shifted, as they have become experts in dealing with the volcanic disaster (Table 2).

\section{Discussion: cross-cultural volcanology}

The poems quoted above show many dimensions of the eruption's social impact, as well as local impressions of the scientists, their role and their limitations. The verse is highly culturally specific, particularly in its strong Christian roots, but offers several points for wider reflection. It is of course accompanied by numerous other artistic expressions from the eruption, most notably in music. There is a need to testify (Alkalay-Gut, 2005), and literature is one medium through which Montserratians have told their stories, not only to one another but to a wider, ill-defined public, consisting of those who choose to read their work and take interest. Poetry in particular enables the capture of fears and uncertainty on paper, in brief intensity. The poems described and quoted above show the depths of feeling that the eruption 
has engendered - beyond the personal and into the personal-national. They capture the distrust of unknown scientific invaders, the ongoing colonial uneasiness, the ignorance of what happens in an eruption and the terrible fears associated with relocation - loss of property, livelihood, privacy. They also describe the development of relationships between the scientists and the islanders and the growth of trust (Haynes et al., 2007a).

One local official on Montserrat described the difference made by a single scientist who visited the shelters, and expressed his disgust in a letter to The Times. Recently the use of local interests in communicating with the population has been shown where scientists joke about the cricket, or know about local music and tradition. Scientists involved on Montserrat have described their own education as they have got to know people over long periods of interaction, and the development of lasting friendships. The cultural atmosphere and the creativity of Montserratians have had lasting impacts on volcanologists and on the directions of their research:

I just liked geophysics... but then when I finally was here and saw the direct impact of this eruption here then it just added something, which makes me also more careful I think in publishing things, in how seriously you should take your models and so, because other people might rely on it. - Senior scientist

Artistic expression is also a measure of education: the penetration of scientific vocabulary into Montserratian poetry, music and prose is striking, even very early in the eruption. The media in Montserrat has been instrumental, in collaboration with scientists and the emergency managers, in educating the local population. ZJB Radio remains the cornerstone of the warning system, and this meant that its personnel had to learn the science at breakneck speed, and often this meant a degree of translation as well as education, and it meant the repeated use of scientific terms to familiarise people with them. Several scientists and local officials described the breakthroughs in public understanding that were made when the scientists spoke directly with the broadcasters in live interviews: the radio was Montserrat's chief source of information, and the people wanted to hear directly from the experts, without the perceived colonial filters. The radio was also a major source of comfort and support for many Montserratians, as they were encouraged to talk about their feelings and ask questions - to share in the experience that they were all going through. It is the main link between the different parts of the diaspora, and along with "The Montserrat Reporter" (also known as "The Montserrat Distorter") is a key information source for those overseas.

Expression of a culture through its literature is a source of local knowledge. Sometimes, it is difficult to understand, but may offer insights into Montserratian culture both pre- and syneruption. One example might be the importance of their Christian faith to many Montserratians; others might be the value ascribed to family land, the ownership of their verdant hills and the abundance of fruit trees - all of these seem relatively minor aspects of a culture, but all affected the ways in which risk was perceived in terms of the loss involved and the interpretation of the volcanic activity, the reasons for it and the likely impacts on "traditional" Montserratian life. The role of farming in local life, for example, was not adequately taken into account early in the eruption, with tragic results: several of those killed in 1997 were tending to farmland and animals. This has been described elsewhere (e.g. Wilson et al., 2009), and amounts to a negation of local culture. Ownership and landscape are tied to livelihoods and survival. 
A fundamental problem with managing the perception of risk is its cultural variability (Jasanoff, 1986). The assumption that understanding the scientific facts and terminology is adequate preparation for dealing with volcanic risk is missing the point. While risk perception depends both on knowledge and on trust, for example (Haynes et al., 2007a), the corporate consciousness also has a role to play. Dominant social discourses indubitably colour societal risk management (e.g. Kahan et al., 2009). On Montserrat, colonialism has played a key role, tainting the words of Western scientists, for example. In addition, top-down management in the early years of the eruption, as a result of the governmental structure on Montserrat, allied scientists with colonial powers and undermined their objectivity in the eyes of the public. Many of these issues are the direct result of poor local knowledge - understandable given the absence of crisis plans and the uncertainties about the magnitude of any potential eruption. However, the increasingly globalised community of volcanologists means that the involvement of non-local scientists in many locations is very likely. The gathering of local knowledge is therefore important in understanding and communicating with other cultures and thus in doing cross-cultural volcanology.

Recent work has demonstrated that even if risk perception is adequate, people do not necessarily take action (Gaillard, 2008). The reasons for this may be social, economic and/or cultural. Thus it is by engagement with the everyday lives and concerns of the local people that risk is most likely to be reduced - dealing with vulnerability to poverty, for example, and effectively increasing the importance of the volcanic risk on the societal risk hierarchy. At the same time, the eruption on Montserrat demonstrates that volcanic activity can pierce the core of a culture in a way that is arguably unique, particularly owing to uncertainties about eruption duration. The social dependence on science that results can be challenging for both sides. On Montserrat, this was complicated by a parallel dependence on a colonial power, and the interaction between different scientific, local and political cultures. In particular, many individuals commented on the delicate racial issues on Montserrat: British scientists were regarded with suspicion by some of the locals because they were identified with the British government. The social context of the science was therefore of great importance in its communication.

An interviewee described the initial scientific outreach on Montserrat as "fabulous": those parts of the population hungry for information about the volcano were satisfied. The comments in the literature do not dispute the calibre of the outreach, but rather express their sadness at its context and the overwhelming helplessness that was forced upon them. There is a difference between volcanology as interesting and volcanology as survival information. One of the key breakthroughs in the eruption occurred when scientists went on the radio and spoke directly to the people, rather than via the politicians and local officials (Pattullo, 2000). This provided a forum for people to ask questions - a key opportunity for scientists to evaluate their own outreach, and to demonstrate their humanity. This has been appreciated by the Montserratians:

But the good thing is that the scientists are always ready to explain, because they too understood - they too, it was a learning experience for them too, because they've never had to deal with people, per se - they had only had to deal with the scientific aspect of it; they'd never had to deal with actual people and the fact that people, how people could be impacted by their closeness to the volcano, and all that sort of stuff. Broadcaster

The experience on Montserrat has provided exempla for scientists and social scientists working in eruptions (Haynes, 2005 and [Druitt and Kokelaar, 2002]_). The arts, however, 
have been more of a curiosity for many, perhaps drawn to them because of association with the volcano rather than with the people. Yet these works offer a measure of the success of education programmes, and of continued engagement with local people and institutions. They also measure the ongoing remaking of an island, as it reflects on its experiences and comes to terms with its new transboundary identities.

\section{Conclusions}

- The expression of tragedy in literature is an ancient human activity, and is associated with catharsis, identification and re-identification.

- Analysis of the cultural products of volcanic eruptions - such as poetry and narrative - can be used to augment and enrich outreach attempts by observatories and scientists during a crisis, and during longer-term volcanic activity. It can also be used to judge the extent to which volcanological vocabulary has penetrated the community. However, scientific jargon can impede the communication process.

- Montserrat's rich cultural heritage has undergone transformations and renewal through the eruption, even as it has experienced tragedy.

- Communication and trust are aided by engagement with local interests, and by awareness of cultural and artistic ideals. In an island nation, the sense of national identity is powerful and is a major factor in gaining trust. On Montserrat, this has been significantly complicated by colonial fears and tensions.

- A key breakthrough on Montserrat occurred when scientists began to speak directly to the media, because this enabled some detachment from colonial suspicions and resentments.

- A major challenge in the communication of uncertainty is teaching people that volcanology is a young science. This has been successful on Montserrat and is evidenced in the poetic record.

- Multidisciplinarity can lead to confusion among locals as they try to understand the way that science works and how scientists interact with each other as well as with the public. Scientific cultures have an impact on the culture around them.

- Literature and other media of cultural expression can aid the gathering of local knowledge, which is important in the communication of risk.

- Given Montserrat's artistic and creative history, poetry (alongside other media, notably calypso) was an obvious outlet for emotions, and also for the expression of very high levels of uncertainty, particularly early in the crisis. It therefore provides insights into the impact that the eruption has had on personalities, on thought patterns, and on the transformation of a culture through a shared disaster.

- Literature is also a means of identification between cultures, suggesting that Montserratian chronicles of their experiences might be of use in communicating volcanic risk to communities that may face it in the future.

\section{Acknowledgements}

AD acknowledges a NERC-ESRC PhD Studentship. The staff of the Montserrat Volcano Observatory (past and present), the members of the Scientific Advisory Committee, Sir Howard Fergus, the Governor, and other citizens of Montserrat are thanked for their input and support during the fieldwork. Two anonymous reviewers are thanked for comments that improved the text of this paper. 


\section{References}

Alkalay-Gut, 2005 Karen Alkalay-Gut, The poetry of September 11: the testimonial imperative. Poetics Today, 262 (2005), pp. 257-279. Aristotle, 1996 Aristotle, Poetics, Penguin, London (1996).

Ashfield and De Bolla, 1996 The Sublime: A Reader in Eighteenth-century Aesthetic Theory, A. Ashfield, P. De Bolla, Editors CUP, Cambridge (1996).

Aspinall, 2006 W.P. Aspinall, Structured elicitation of expert judgement for probabilistic hazard and risk assessment in volcanic eruptions, S.C.H.M. Mader, C. Connor, L. Connor, Editors Statistics in Volcanology, 1 Geological Society of London, London (2006), pp. 1530 .

Aspinall and Sparks., 2004 Aspinall, W.P., Sparks, R.S.J. (2004). Volcanology and the law. IAVCEI News 1: 4-5, 11-12..

Aspinall et al., 2002 W.P. Aspinall, S.C. Loughlin, F.V. Michael, A.D. Miller, G.E. Norton, K.C. Rowley, R.S.J. Sparks and S.R. Young, The Montserrat Volcano Observatory: its evolution, organization, role and activities, The Eruption of Soufriere Hills Volcano, Montserrat, from 1995 to 1999, 21 ,in: T.H. Druitt, B.P. Kokelaar, Editors Geological society Memoir, London (2002), pp. 71-91

Barclay et al., 2008 J. Barclay, K. Haynes, T. Mitchell, C. Solana, R. Teeuw, A. Darnell, S. Crosweller, P. Cole, D. Pyle, C. Lowe, C. Fearnley and I. Kelman, Framing volcanic risk communication within disaster risk reduction: finding ways for the social and physical sciences to work together. Geological Society, London, Special Publications, 3051 (2008), pp. 163-177.

Barthes, 1967 R. Barthes, The death of the author. Aspen, (1967), pp. 5-6.

Bate, 2000 Jonathan Bate, The Song of the Earth, Harvard University Press, Cambridge MA (2000).

Bird et al., 2009 D.K. Bird, G. Gisladottir and D. Dominey-Howes, Public perception of jokulhlaup hazard and risk in Iceland: implications for community education. International Journal of Management and Decision Making, 10 3-4 (2009), pp. 164-175

Boitani, 1989 Piero Boitani, The Tragic and the Sublime in Medieval Literature, Cambridge Univ. Press, Cambridge (1989).

Burke, 1757 Edmund Burke, A Philosophical Enquiry into Our Ideas of the Sublime and Beautiful, (1757).

Burke, 1790 Edmund Burke, Reflections on the Revolution in France, (1790).

Cashman and Cronin, 2008 K.V. Cashman and S.J. Cronin, Welcoming a monster to the world: myths, oral tradition and modern societal response to volcanic disasters. Journal of Volcanology and Geothermal Research, 1763 (2008), pp. 407-418 
Chester, 2005 D.K. Chester, Theology and disaster studies: the need for dialogue. Journal of Volcanology and Geothermal Research, 1464 (2005), pp. 319-328.

Chester et al., 2008 David K. Chester, Angus M. Duncan and Christopher J.L. Dibben, The importance of religion in shaping volcanic risk perception in Italy, with special reference to Vesuvius and Etna. Journal of Volcanology and Geothermal Research, 172 3-4 (2008), pp. 216-228.

Clay et al., 1999 E.B. Clay, C. Barrow, C. Benson, J. Dempster, B.P. Kokelaar, N. Pillai and J. Seaman, An Evaluation of HMG's Response to the Montserrat Volcanic Emergency, Department for International Development, London (1999).

Collins and Evans, 2002 Harry Collins and Robert Evans, The third wave of science studies: studies of expertise and experience. Social Studies of Science, 322 (2002), pp. 235-296. |

Cronin et al., 2004 S.J. Cronin, D.R. Gaylord, D. Charley, B.V. Alloway, S. Wallez and J.W. Esau, Participatory methods of incorporating scientific with traditional knowledge for volcanic hazard management on Ambae Island, Vanuatu. Bulletin of Volcanology, 667 (2004), p. 652

Donovan, 2010 Donovan, A.R. (2010). Emerald and andesite: volcanology at the policy interface on Montserrat. Unpublished $\mathrm{PhD}$ thesis, University of Cambridge..

Druitt and Kokelaar, 2002 T.H. Druitt and B.P. Kokelaar, The Eruption of the Soufriere Hills Volcano, Montserrat, from 1995 to 1999, Geological Society Memoir No. 21, Geological Society, London (2002).

Eagleton, 2003 Terry Eagleton, Sweet Violence: The Idea of the Tragic, Blackwell, Oxford (2003).

Empson, 1930 William Empson, Seven Types of Ambiguity, Chatto and Windus, London (1930).

Fergus, 1996 Howard A. Fergus, Editor, Eruption: Montserrat Versus Volcano, University of the West Indies School of Continuing Studies, Montserrat (1996).

Fergus, 2003 Howard A. Fergus, Volcano Verses, Peepal Tree, Leeds (2003).

Fergus, 2004 Howard A. Fergus, Montserrat: History of a Caribbean Colony, Macmillan, Oxford (2004).

Fischer, 2004 Frank Fischer, Are scientists irrational? Risk assessment in practical reason, Melissa Leach, Ian Scoones, Brian Wynne, Editors, Science and Citizens: Globalization and the Challenge of Engagement, Zed Books, London (2004), pp. 54-65.

Foucault, 1969 Michel Foucault, What is an author?, Lodge David, Editor, Modern Criticism and Theory (2000), Longman, New York (1969).

Foucault, 1968 Michel Foucault, On the archaeology of the sciences. English Translation in Theoretical Practice, (1968), pp. 3-4 
Gaillard, 2008 J.-C. Gaillard, Alternative paradigms of volcanic risk perception: the case of Mt. Pinatubo in the Philippines. Journal of Volcanology and Geothermal Research, 172 3-4 (2008), p. 315.

Gaillard and Dibben, 2008 J.C. Gaillard and C.J.L. Dibben, Risk perception and beyond. Journal of Volcanology and Geothermal Research, 172 3-4 (2008), pp. 163-169.

Geertz, 1973 C. Geertz, The Interpretation of Cultures, Basic Books, New York (1973).

Gregg et al., 2004 C.E. Gregg, B.F. Houghton, D.M. Johnston, D. Paton and D.A. Swanson, The perception of volcanic risk in Kona communities from Mauna Loa and Hualalai volcanoes, Hawai'i. Journal of Volcanology and Geothermal Research, 130 (2004), pp. 179196.

Haynes, 2005 Haynes, K. (2005). Exploring the communication of risk during a volcanic crisis: a case study of Montserrat, W.I. Unpublished Ph.D thesis. University of East Anglia,..

Haynes et al., 2007a K. Haynes, J. Barclay and N. Pidgeon, Volcanic hazard communication using maps: an evaluation of their effectiveness. Bulletin of Volcanology, 702 (2007), pp. $123-138$

Haynes et al., 2007b K. Haynes, J. Barclay and N. Pidgeon, The issue of trust and its influence on risk communication during a volcanic crisis. Bulletin of Volcanology, 705 (2007), pp. 605-621.

Haynes et al., 2008 K. Haynes, J. Barclay and N. Pidgeon, Whose reality counts? Factors affecting the perception of volcanic risk. Journal of Volcanology and Geothermal Research, 172 3-4 (2008), p. 259.

Jasanoff, 1986 Jasanoff, S., 1986. Risk management and political culture. Social Research Perspectives 12 .

Jasanoff, 2003 S. Jasanoff, Technologies of humility: citizen participation in governing science. Minerva, 41 (2003), pp. 223-244

Johnston and Ronan, 2000 D. Johnston and K. Ronan, Risk education and intervention, H. Sigurdsson, Editor, Encyclopedia of Volcanoes, Academic Press, New York (2000), pp. 1229-1240.

Johnston et al., 2000 D.M. Johnston, B.F. Houghton, V.E. Neall, K.R. Ronan and D. Paton, Impacts of the 1945 and 1995-1996 Ruapehu eruptions, New Zealand: an example of increasing societal vulnerability. Geological Society of America Bulletin, 1125 (2000), pp. 720-726

Kahan, 2010 D. Kahan, Fixing the communications failure. Nature, 4637279 (2010), p. 296.

Kahan et al., 2009 D.M. Kahan, D. Braman, P. Slovic, J. Gastil and G. Cohen, Cultural cognition of the risks and benefits of nanotechnology. Nature Nanotechnology, 42 (2009), p. 87. 
Kant, 2005 Immanuel Kant, "The analytic of the sublime", in Critique of Judgement (1790), trans, J. Bernard, Dover, New York (2005).

Kokelaar, 2002 B.P. Kokelaar, Setting, chronology and consequences of the eruption of Soufriere Hills Volcano, Montserrat (1995-1999), The Eruption of Soufriere Hills Volcano, Montserrat, from 1995 to 1999, 21 ,in: T.H. Druitt, B.P. Kokelaar, Editors Geological society Memoir, London (2002), pp. 1-43.

$\underline{\text { Kubler-Ross, } 1969}$ Elizabeth Kubler-Ross, On Death and Dying, Tavistock, London (1969), 1970.

Latour, 1987 B. Latour, Science in Action: How to Follow Scientists and Engineers through Society, Harvard University Press, Cambridge (1987).

Loughlin et al., 2002 S.C. Loughlin, P.J. Baxter, W.P. Aspinall, B. Darroux, C.L. Harford and A.D. Miller, Eyewitness accounts of the 25 June 1997 pyroclastic flows and surges at Soufriere Hills Volcano, Montserrat, and implications for disaster mitigation, The Eruption of Soufriere Hills Volcano, Montserrat, from 1995 to 1999, 21 ,in: T.H. Druitt, B.P. Kokelaar, Editors Geological society Memoir, London (2002), pp. 211-230.

Loughlin et al., 2010 Loughlin, S.C., Luckett, R., Ryan, G., Christopher, T., Hards, V., De Angelis, S., Jones, L., Strutt, M., 2010. An overview of lava dome evolution, dome collapse and cyclicity at Soufriere Hills Volcano, Montserrat, 2005-2007. Geophysical Research Letters 37, L00E16..

Markham, 1989 E.A. Markham, Hinterland: Caribbean Poetry from the West Indies and Britain, Bloodaxe (1989).

Marzocchi and Woo, 2009 W. Marzocchi and G. Woo, Principles of volcanic risk metrics: theory and the case study of Mount Vesuvius and Campi Flegrei, Italy. Journal of Geophysical Research, 114 (2009).

Marzocchi et al., 2006 W. Marzocchi, L. Sandri and C. Furlan, A quantitative model for volcanic hazard assessment, Statistics in Volcanology, 1 , in: S.C.H.M. Mader, C. Connor, L. Connor, Editors Geological Society, London (2006).

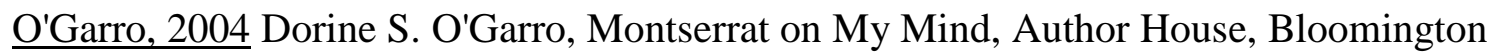
(2004), 2004.

Pattullo, 2000 Polly Pattullo, Fire from the Mountain: The Tragedy of Montserrat and the Betrayal of its People, Constable, London (2000).

Perry and Liddell, 2008 R.W. Perry and M.K. Lindell, Volcanic risk perception and adjustment in a multi-hazard environment. Journal of Volcanology and Geothermal Research, 172 3-4 (2008), p. 170

Poole, 1987 Adrian Poole, Tragedy: Shakespeare and the Greek Example, Blackwell, Oxford (1987).

Poole, 2005 Adrian Poole, Tragedy: A Very Short Introduction, OUP, Oxford (2005). 
Possekel, 1999 A. Possekel, Living with the Unexpected: Linking Disaster Recovery to Sustainable Development in Montserrat, Springer, Berlin (1999).

$\underline{\text { Richards, } 1929}$ I.A. Richards, Practical Criticism: A Study of Literary Judgement, K. Paul, London (1929).

Shapiro, 1985 Gary Shapiro, From the sublime to the political: some historical notes. New Literary History, 162 (1985), pp. 213-235.

Skinner, 2004 Jonathan Skinner, Before the Volcano: Reverberations of Identity on Montserrat, Arawak, London (2004).

Somekh and Lewin, 2005 Somekh, B., Lewin, C. (Eds.), 2005. Research methods in the social sciences. Sage, London..

Sparks and Young, 2002 R.S.J. Sparks and S.R. Young, The eruption of Soufriere Hills Volcano, Montserrat (1995-1999): overview of scientific results, The Eruption of Soufriere Hills Volcano, Montserrat, from 1995 to 1999, 21 ,in: T.H. Druitt, B.P. Kokelaar, Editors Geological society Memoir, London (2002), pp. 45-69.

Swanson, 2008 D.A. Swanson, Hawaiian oral tradition describes 400 years of volcanic activity at Kilauea. Journal of Volcanology and Geothermal Research, 1763 (2008), pp. 427-431.

Wadge and Isaacs, 1988 G. Wadge and M. Isaacs, Mapping the volcanic hazards from the Soufriere Hills Volcano, Montserrat, West Indies, using an image processor. Journal of the Geological Society, London, 145 (1988), pp. 541-551.

Wadge et al., 2010 G. Wadge, R. Herd, G. Ryan, E.S. Calder and J.C. Komorowski, Lava production at Soufrière Hills Volcano, Montserrat: 1995-2009. Geophysical Research Letters, 37 (2010), p. L00E03.

Watts et al., 2002 R.B. Watts, R.A. Herd, R.S.J. Sparks and S.R. Young, Growth patterns and emplacement of the andesitic lava dome at Soufriere Hills Volcano, Montserrat, The Eruption of Soufriere Hills Volcano, Montserrat, from 1995 to 1999, 21 ,in: T.H. Druitt, B.P. Kokelaar, Editors Geological society Memoir, London (2002), pp. 115-152.

Weekes, 2006 Yvonne Weekes, Volcano: A Memoir, Peepal Tree, Leeds (2006).

Wilson et al., 2009 T. Wilson, C. Stewart, J. Cole, D.M. Johnston and S. Cronin, Vulnerability of farm water supply systems to volcanic ash fall. Environmental Earth Sciences, 614 (2009), p. 675.

Wynne, 2003 Brian Wynne, Seasickness on the third wave? Subverting the hegemony of propositionalism: response to Collins and Evans, 2002. Social Studies of Science, 33 (2003), pp. 401-417 
Table 1. Eruption chronology. Shaded areas denote periods of extrusion

\begin{tabular}{|c|c|}
\hline Date & Event \\
\hline $\begin{array}{l}18 \text { July } 1995-15^{\text {th }} \\
\text { November } 1995\end{array}$ & $\begin{array}{l}\text { Phreatic explosions, which were associated with } \\
\text { vent openings around the crater and significant } \\
\text { ashing in Plymouth and nearby villages }\end{array}$ \\
\hline $15^{\text {th }}$ November 1995 & $\begin{array}{l}\text { First observation of fresh magma at the surface: } \\
\text { growth commenced. }\end{array}$ \\
\hline $17^{\text {th }}$ September 1996 & $\begin{array}{l}\text { 9-hour sequence of dome collapses, plume rose } \\
\text { to } 14 \mathrm{~km} \text { and pumice fall in the south }\end{array}$ \\
\hline $\begin{array}{l}1 \text { October } 1996-24 \\
\text { June } 1997\end{array}$ & $\begin{array}{l}\text { Continued dome growth, varying in intensity and } \\
\text { location around the crater. Galways Wall shows } \\
\text { signs of degradation. }\end{array}$ \\
\hline 25 June 1997 & $\begin{array}{l}\text { Large collapse sent flows to the airport in the east } \\
\text { and into the Belham Valley in the west. Nineteen } \\
\text { people were killed. }\end{array}$ \\
\hline 3 August 1997 & $\begin{array}{l}\text { Large collapse sent pyroclastic flows through } \\
\text { central Plymouth }\end{array}$ \\
\hline 4-12 August 1997 & $\begin{array}{l}10 \text { Vulcanian explosions, roughly every } 12 \text { hours. } \\
\text { Intense pumice fall over most of the island }\end{array}$ \\
\hline $\begin{array}{l}12^{\text {th }} \text { August to } 20 \\
\text { September } 1997\end{array}$ & $\begin{array}{l}\text { Continued rapid dome growth, associated with } \\
\text { pyroclastic flows. MVO was moved from Old Towne } \\
\text { to the North. }\end{array}$ \\
\hline 21 September 1997 & $\begin{array}{l}\text { Large dome collapse to the north-east destroys the } \\
\text { airport }\end{array}$ \\
\hline $\begin{array}{l}22^{\text {nd }} \text { September to } 21^{\text {st }} \\
\text { October }\end{array}$ & $\begin{array}{l}76 \text { repetitive Vulcanian explosions at } 10 \text { hour } \\
\text { intervals, causing a plume to } 40,000 \text { feet and ash } \\
\text { and pumice fall all over the island }\end{array}$ \\
\hline $\begin{array}{l}22^{\text {nd }} \text { October to } 24^{\text {th }} \\
\text { December } 1997\end{array}$ & $\begin{array}{l}\text { Ongoing dome growth, with collapses on } 4^{\text {th }} \text { and } \\
6^{\text {th }} \text { November }\end{array}$ \\
\hline $25-26^{\text {th }}$ December & $\begin{array}{l}\text { Intense seismic activity followed by the "Boxing } \\
\text { Day event", which saw Galway's Wall and the SW } \\
\text { flank collapse, undermining the dome and causing } \\
\text { a debris avalanche followed by huge pyroclastic } \\
\text { flows. This event is regarded by some as a lateral } \\
\text { blast. }\end{array}$ \\
\hline $\begin{array}{l}27^{\text {th }} \text { December }-7^{\text {th }} \\
\text { March } 1998\end{array}$ & $\begin{array}{l}\text { Continued dome growth and seismicity, but } \\
\text { diminishing. }\end{array}$ \\
\hline $8^{\text {th }}-10^{\text {th }}$ March 1998 & Dome growth ceases \\
\hline $11^{\text {th }}$ March to $2^{\text {nd }}$ July 1998 & $\begin{array}{l}\text { Residual activity, dome erosion, some seismic } \\
\text { activity }\end{array}$ \\
\hline $3^{\text {rd July } 1998}$ & Large dome collapse, followed by a small explosion \\
\hline $22^{\text {nd }}-23^{\text {rd }}$ May 1999 & $\begin{array}{l}\text { Dome collapse down Tar River Valley, associated } \\
\text { with } 121 \text { VTs }\end{array}$ \\
\hline $3^{\text {rd }}-9^{\text {th }}$ September 1999 & Explosion followed by collapse events \\
\hline $\begin{array}{l}10^{\text {th }} \text { September to } 20^{\text {th }} \\
\text { October } 1999\end{array}$ & Low levels of activity, some small pyroclastic flows \\
\hline $\begin{array}{l}21^{\text {st }} \text { October }-26^{\text {th }} \\
\text { November } 1999\end{array}$ & $\begin{array}{l}\text { Explosive and seismic activity. Hurricane Lenny } \\
\text { caused mudflows and venting. }\end{array}$ \\
\hline $\begin{array}{l}27^{\text {th }} \text { November } 1999-20^{\text {th }} \\
\text { March } 2000\end{array}$ & Dome growth \\
\hline $20^{\text {th }}$ March 2000 & Dome collapse, possibly due to heavy rain. \\
\hline March 2000 - July 2001 & Dome growth \\
\hline $29^{\text {th July } 2001}$ & Major dome collapse on eastern flank \\
\hline August 2001 - July 2003 & Dome growth \\
\hline $2^{\text {nid }}$ October 2002 & Small collapse \\
\hline $9^{\text {th }}$ December 2002 & Small collapse \\
\hline $12^{\text {th }}-13^{\text {th }}$ July 2003 & Major dome collapse \\
\hline $13^{\text {th }}$ July $-1^{x}$ August 2003 & $\begin{array}{l}\text { Three vulcanian explosions, followed by dome } \\
\text { growth and ash venting }\end{array}$ \\
\hline $2^{\text {nd }}$ August 2003 & Dome growth ceased \\
\hline
\end{tabular}




\begin{tabular}{|c|c|}
\hline Date & Event \\
\hline $\begin{array}{l}2^{\text {nd }} \text { August } 2003-2^{\text {nd }} \\
\text { March } 2004\end{array}$ & $\begin{array}{l}\text { No dome growth. Some periods of high } \mathrm{SO} 2 \\
\text { emission. }\end{array}$ \\
\hline $3^{\text {rd }}$ March 2004 & Dome collapse \\
\hline $\begin{array}{l}4^{\text {th }} \text { March } 2004-14 \text { April } \\
2005\end{array}$ & $\begin{array}{l}\text { Residual activity, some seismic swarms and intense } \\
\text { degassing }\end{array}$ \\
\hline $15^{\text {th }}$ April $-27^{\text {th }}$ June 2005 & Phreatic activity and ash venting \\
\hline $28^{\text {th }}$ June $-7^{\text {th }}$ August 2005 & Explosive activity \\
\hline $\begin{array}{l}8^{\text {th }} \text { August } 2005-\text { May } 19^{\text {th }} \\
2006\end{array}$ & Dome growth \\
\hline $20^{\text {th }}$ May 2006 & Large dome collapse \\
\hline $\begin{array}{l}21^{\text {st }} \text { May } 2006-7^{\text {th }} \\
\text { January } 2007\end{array}$ & Dome growth \\
\hline $8^{\text {th }}$ January 2007 & Collapse of the dome into the Belham Valley \\
\hline $\begin{array}{l}9^{\text {th }} \text { January - April 3rd } \\
2007\end{array}$ & Dome growth \\
\hline $4^{\text {th }}$ April 2007 & Cessation of dome growth \\
\hline April 2007 - July 2008 & No dome growth \\
\hline $\begin{array}{l}13^{\text {th }}, 23^{\text {rd }} \text { and } 29^{\text {th }} \\
\text { May } 2008\end{array}$ & Small explosions \\
\hline $21^{\text {st }}-27^{\text {th }}$ July 2008 & Onset of mild venting and seismic activity \\
\hline $28^{\text {th }}$ July 2008 & Large explosive event generating $12 \mathrm{~km}$ column \\
\hline $\begin{array}{l}8^{\text {th }} \text { August }-15^{\text {th }} \text { October } \\
2008\end{array}$ & Dome growth \\
\hline $\begin{array}{l}26^{\text {th }} \text { October - } 1 \text { December } \\
2008\end{array}$ & Residual activity, some weak ashing \\
\hline $2^{\text {nd }}$ December 2008 & Explosive event and collapse generating large flows \\
\hline $\begin{array}{l}10^{\text {th }} \text { December } 2008-2^{\text {nd }} \\
\text { January } 2009\end{array}$ & Dome growth, high extrusion rate \\
\hline $3^{\text {rd }}$ January 2009 & Large explosion sent an ash column to $11 \mathrm{~km}$ \\
\hline $4^{\text {th }}$ January - October 2009 & Ash venting \\
\hline $\begin{array}{l}4^{\text {th }} \text { January - October } \\
2009\end{array}$ & Ash venting \\
\hline $\begin{array}{l}9^{\text {th }} \text { October } 2009-11^{\text {th }} \\
\text { February } 2010\end{array}$ & Dome growth \\
\hline $11^{\text {th }}$ February 2010 & Dome collapse to the north \\
\hline $\begin{array}{l}11^{\text {th }} \text { February } 2010 \\
\text { - present }\end{array}$ & Residual activity; no dome growth \\
\hline
\end{tabular}




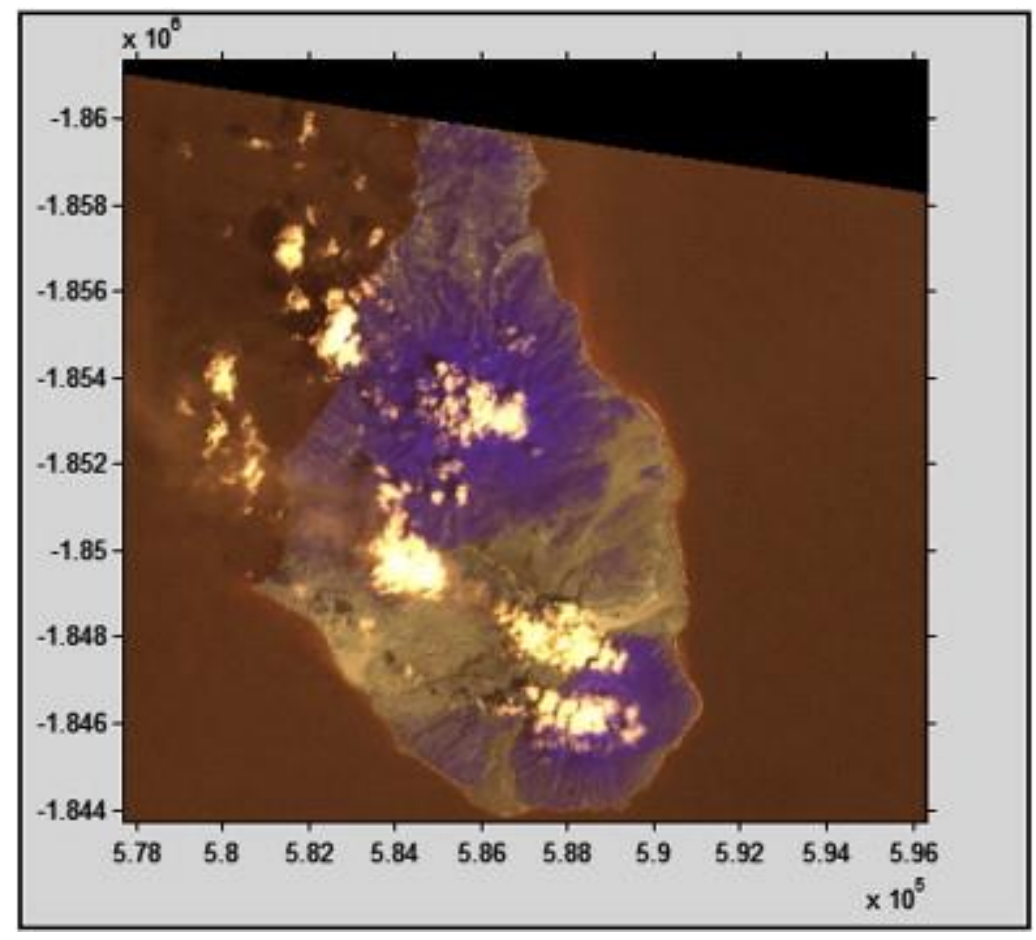

Fig. 1. : Georeferenced ASTER image of Montserrat, March 2007 (using visible/near infrared bands V1, V2, and V3B). Greenish areas represent pyroclastic flow and lahar deposits from the eruption; blue areas are heavily vegetated. 


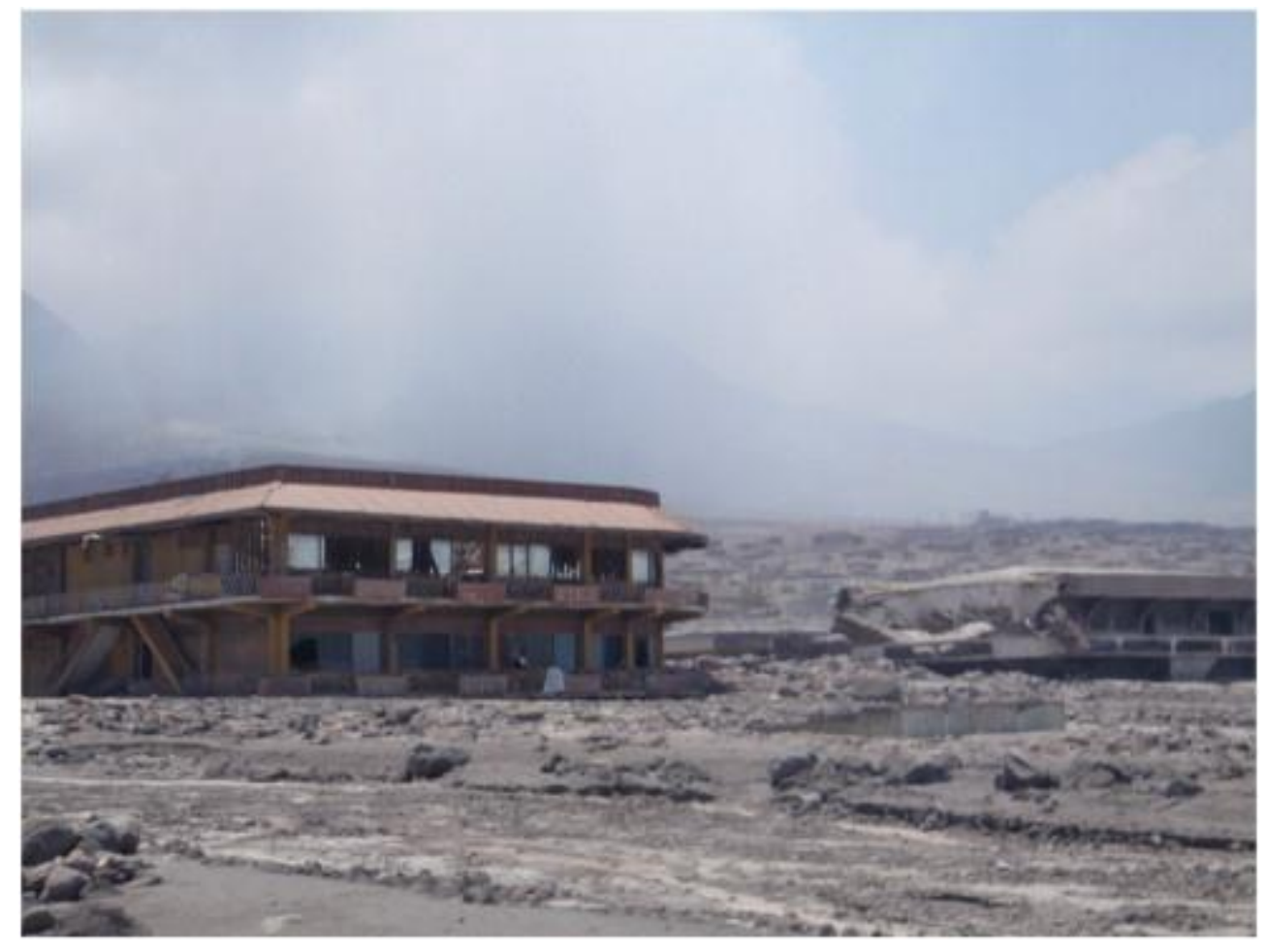

Fig. 2. : Plymouth, June 2008. 


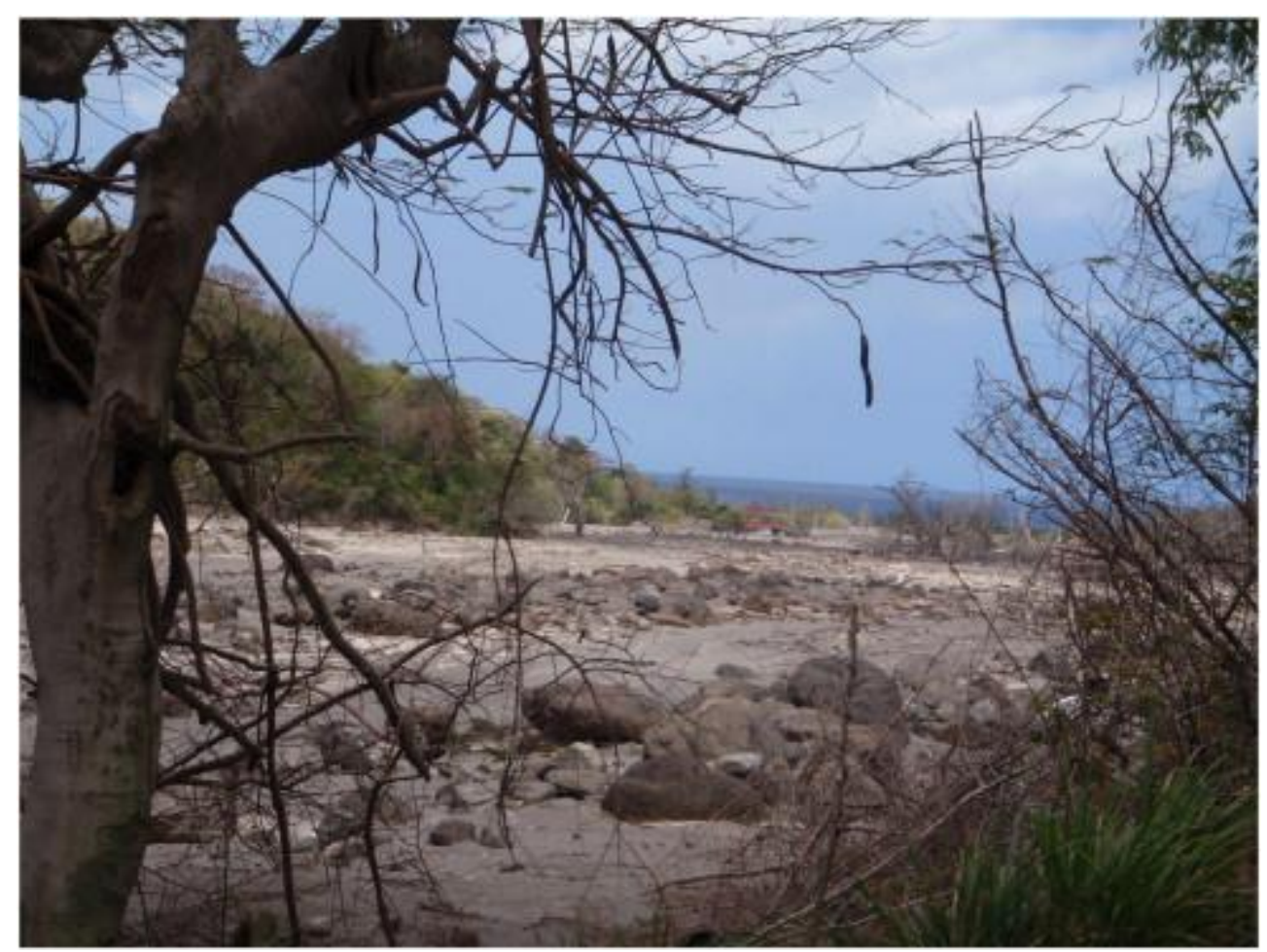

Fig. 3. : The Belham Valley once had a river flowing through it. Now the valley is half-filled with lahar deposits, and in times of heavy rain, these are mobilised into a powerful torrent. 


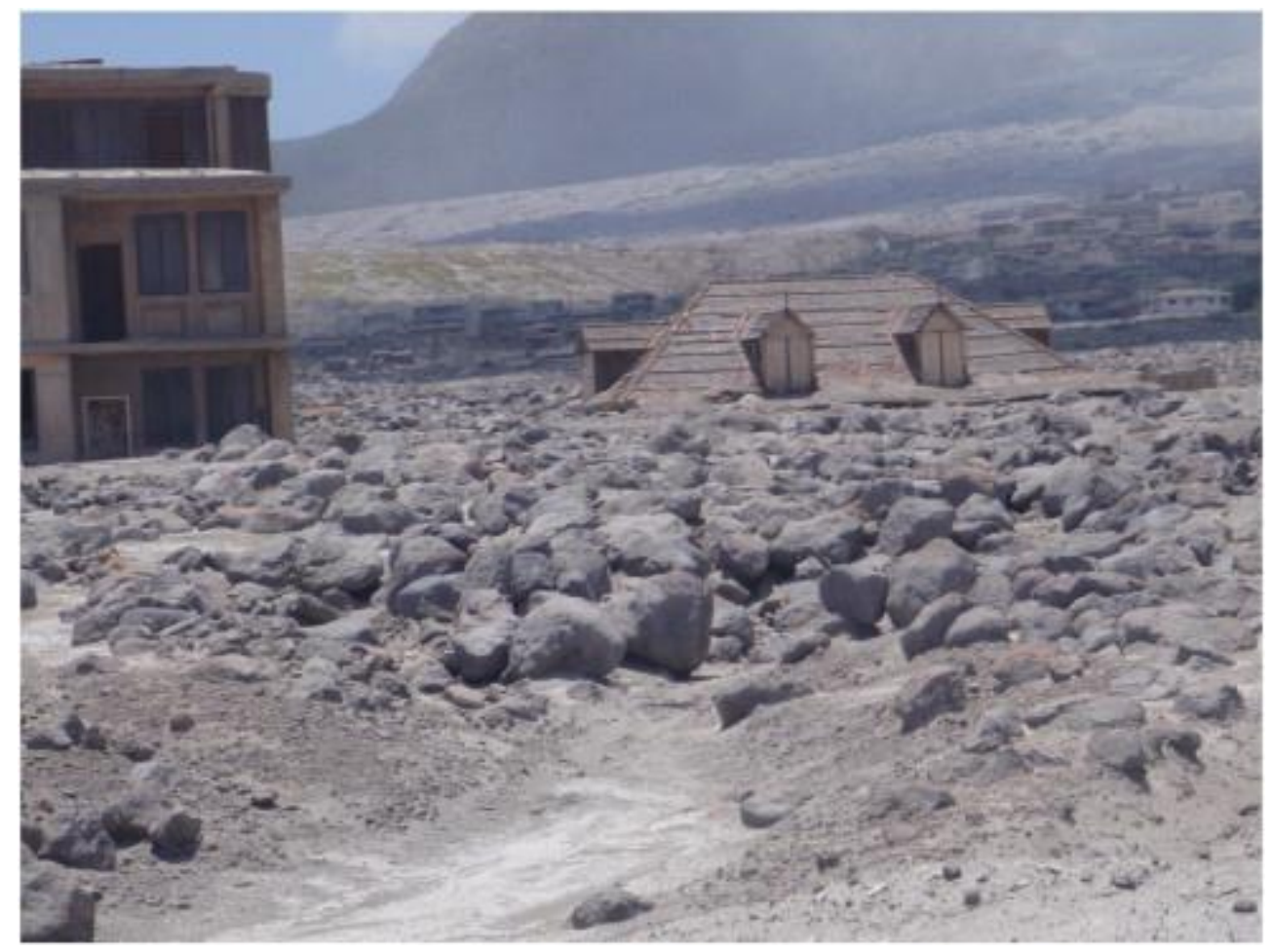

Fig. 4. : Plymouth, June 2008. 


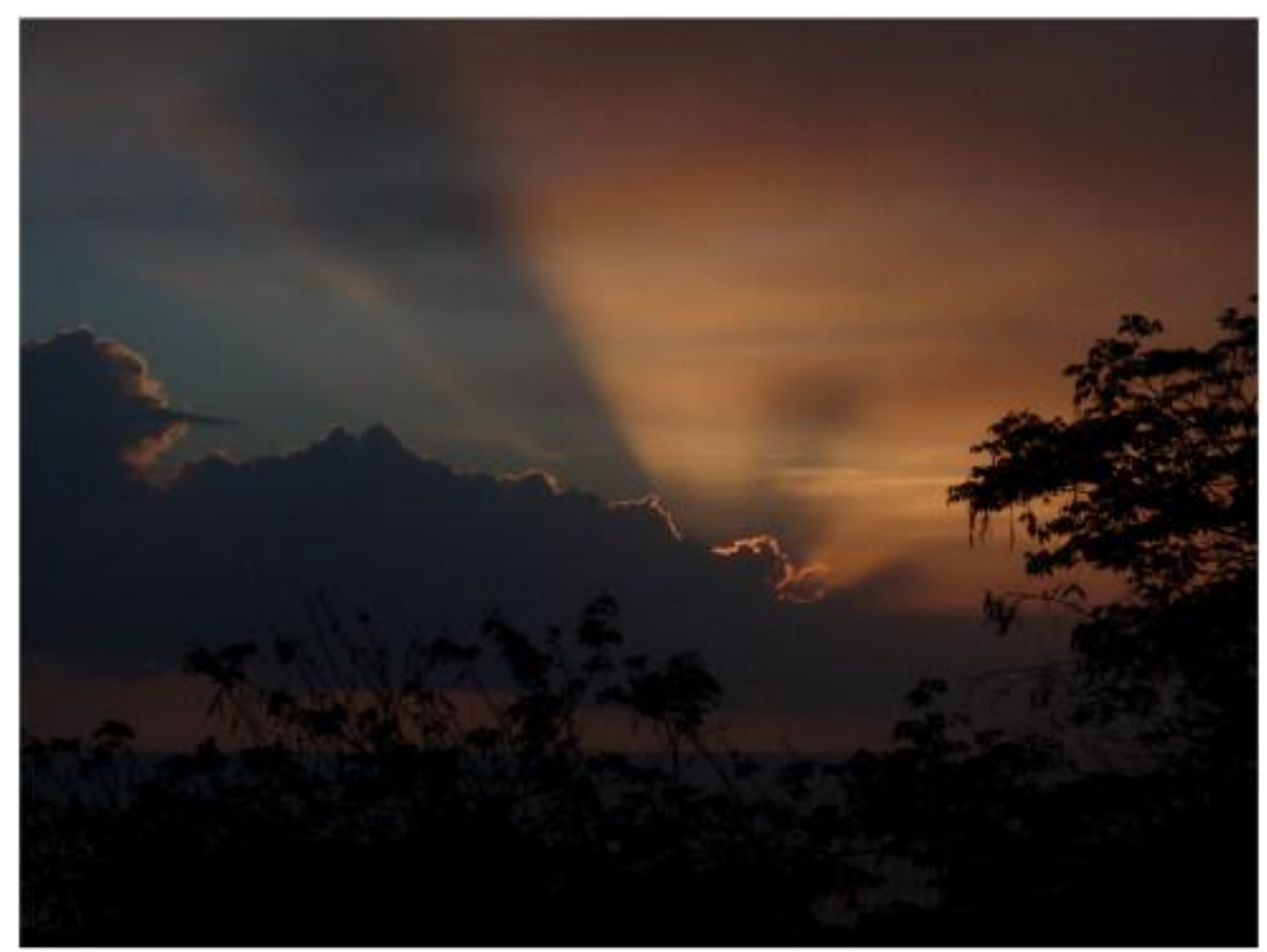

Fig. 5. : Ashy sunset in May 2008. 